Original article

\title{
Comparative seasonal and spatial distribution of decapod larvae assemblages in three coastal zones off the south-western Iberian Peninsula
}

\author{
J.I. González-Gordillo *, A. Rodríguez \\ Instituto de Ciencias Marinas de Andalucía (CSIC), Apdo Oficial, 11510 Puerto Real (Cádiz), Spain
}

\begin{abstract}
Plankton studies over the long southern coast of Iberian Peninsula are very scarce and restricted to a few specific taxonomic groups. In order to know the dynamic of decapod larvae coastal assemblages from south-western of Iberian Peninsula, three zones were studied: Guadalquivir Estuary, Cádiz Bay and Algeciras Bay. The three zones differ by their freshwater inflow and turbidity (highest in Guadalquivir Estuary), primary production (highest in Cádiz Bay) and nutrient concentrations (lowest in Algeciras Bay). The material is based upon plankton samples $(250 \mu \mathrm{m}$ mesh) collected monthly at eight stations distributed between these zones, during 1 year. Maximum values of abundance and diversity were found in Cádiz Bay, while the lowest were recorded in Algeciras Bay. Brachyura was the main abundant taxonomic group in larval decapod assemblages, while Dendrobranchiata, Palinura, Stenopodidea, and Astacidea were scarcely represented or absent. From the 69 taxa identified, 11 were considered rare and 12 taxa constituted $87 \%$ of the total larvae collected. Liocarcinus spp. was the most representative taxon, being present in all stations and showing high abundance and dominance values. The annual distribution was specifically studied for Liocarcinus spp., Carcinus maenas, Xantho spp., Ilia nucleus, Uca tangeri, Brachynotus spp., Hippolyte spp., Philocheras spp., Pisidia longicornis, Diogenes pugilator, Pilumnus spp. and Upogebia sp. Attending to the temporal distribution of dominant taxa, three abundance patterns are shown for decapod larvae at study zones: (i) species present in non-warm months; (ii) species present in warm months; (iii) species present through all year.
\end{abstract}

C 2003 Éditions scientifiques et médicales Elsevier SAS. All rights reserved.

Keywords: Crustacea; Decapoda; Zooplankton; Zoea; Iberian Peninsula

\section{Introduction}

Of the organisms from neritic zooplankton, decapod larvae constitute an important part of the meroplankton, e.g. (Azeiteiro et al., 1999; Fusté, 1987; Locke and Corey, 1988; Roff et al., 1984), and play important role on fish larval feeding (Drake and Arias, 1993). Nevertheless, despite that decapod fauna is very abundant in South-western Iberian Peninsula, in which 377 species can occur (GonzálezGordillo et al., 2001), and many of them are commercially exploited, there is a singular lack of studies describing the seasonal and spatial distribution of its larval populations. The main research results on decapod larvae dynamics in Iberian Peninsula were summarised by Vives (Vives, 1979), Paula (1987, 1989), Fusté (1982, 1990), Fusté and Gili (1991), and

\footnotetext{
* Corresponding author. Present address: Departamento de Biologia, Universidade de Aveiro, 3810-193 Aveiro, Portugal.

E-mail address: nacho.gonzalez@bio.ua.pt (J.I. González-Gordillo).
}

Dos Santos (1999). Nevertheless, except Rodríguez et al. (1997) and Drake et al. (1998), very little is known about the detailed quantitative distribution of decapod larvae in Gulf of Cádiz and surrounding areas.

The Gulf of Cádiz, situated on the SW Iberian Peninsula Fig. 1, is a particular oceanographic seat in where water masses from Atlantic Ocean and Mediterranean Sea meet, characterised by high fishery productivity. The tidal regime is semidiurnal, mean tidal range $2 \mathrm{~m}$, and the long-shore current moves SE-NW following the coastline (Benavente et al. 2000). In this area, three zones were selected and surveyed according to the assumption that they present different seasonal evolution of the water's physical and chemical variables. Guadalquivir Estuary is a non stratified estuary with a gradual horizontal change of the water salinity. The location of the estuarine mixing zone changes from high tide to low tide and seasonally, but the sea water flow (tidal movements) normally penetrates about $20 \mathrm{~km}$ river up on average (Drake et al. 1999). A dam located about $100 \mathrm{~km}$ upstream the river 

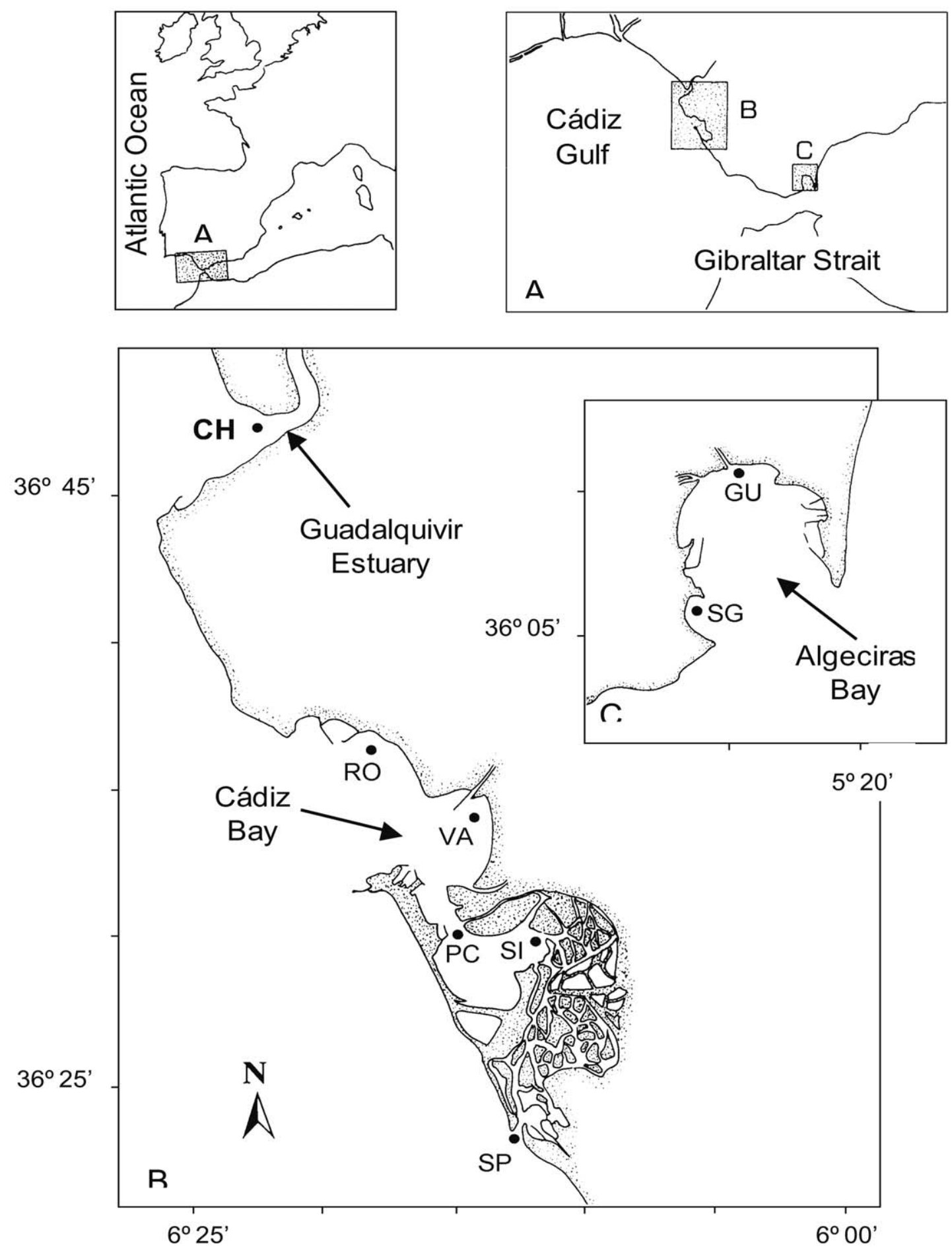

Fig. 1. Geographical location of the sampling stations.

mouth regulates the discharge of freshwater, from 5 (dryseason) up to $90 \mathrm{hm}^{3} \mathrm{D}^{-1}$ (wet season), causing important changes in the salinity values (see Results). Cádiz Bay is a shallow water coastal ecosystem with a surface area of $300 \mathrm{~km}^{2}$, of which $60 \mathrm{~km}^{2}$ are salt ponds. This bay is subdivided into two basins, a shallower one (Inner Bay, average depth of $4 \mathrm{~m}$ ) and a deeper one (Outer Bay, average depth of $10 \mathrm{~m}$ ), connected by a narrow channel. Freshwater inflow is insignificant except during heavy rains and a high productiv- ity is provided by high irradiation, temperature and anthropogenic inputs of organic matter. Mainly, the Cádiz Bay and the Guadalquivir Estuary are of considerable value both ecologically (as primary nursery areas and breeding grounds for fish and decapod) and economically (as fin- and shell fishing areas) (Drake and Arias, 1991a; Fernández-Delgado et al., 2000; Rodríguez, 1981). Algeciras Bay is one of the deepest bay of European continent (up to $500 \mathrm{~m}$ ) spreading over $78 \mathrm{~km}^{2}$. This system is directly influenced by the mixing 
of Atlantic and Mediterranean waters. The tidal influence is scarce but the sea currents cause a high water renewal. Freshwater inflow is almost undetectable, including in strong rains periods. Two of the main characteristics of Algeciras Bay water samples are the low nutrient concentration and chlorophyll values, often not detectable (unpublished data).

Considering the absence of information about coastal zooplanktonic assemblages from the Cádiz Gulf and because the three selected zones support a high human impact, an effort was made to obtain more information about the zooplankton ecology of this area, helping on a better understanding of the functioning of these coastal ecosystems and predicting effects of changes, whether induced by man or not. Thus, the present study was aimed to compare the composition and distribution of larval decapod assemblages in three neighbour coastal areas of the Iberian Peninsula, with similar adults species composition but differing on their hydrological conditions.

\section{Materials and methods}

Sampling was carried out from January to December 1996 at monthly intervals. A total of eight sampling stations, mentioned above, were placed in three different zones Fig. 1: $\mathrm{CH}$ station (7 m depth) at Guadalquivir Estuary; RO $(13 \mathrm{~m})$, VA (5 m), PC (10 m), SI (5 m) and SP (5 m) stations at Cádiz Bay; SG (10 m) and GU (15 m) stations at Algeciras Bay. Samples were collected by oblique tows from bottom to surface, with a $0.4 \mathrm{~m}$ (mouth diameter) conical net $(250 \mu \mathrm{m}$ mesh), equipped with a HydroBios unidirectional current meter. In order to eliminate differences attributable to nychthymeral migrations, sampling was performed during the morning (09:00-13:00 h). For each replicate sample the mean filtered volume was $35.7 \mathrm{~m}^{3}$, fluctuating between 27.3 and $60.6 \mathrm{~m}^{3}$. Samples were immediately preserved in buffered formaldehyde (4\%). All the decapod larvae thus caught, except megalopae, were sorted in the laboratory, counted and identified to the species level, when possible. The lack of larval descriptions for many species precluded identification in many cases. At $\mathrm{CH}$ station, samples were not available in December due to strong storms in the area. Water temperature and salinity measurements were recorded in situ from surface to bottom, at $5 \mathrm{~m}$ intervals.

Dominance $(\% \mathrm{D})$, constancy $(\% \mathrm{C})$ and indices of species richness, Shanon-Wiener diversity and evenness were calculated for each station. Constancy is defined as the relationship between the number of samples collected in a station where a species has been found and the total number of samples collected in this station. Thus, taxa were termed "rare taxa" in a station, if constancy was $<10 \%$ (only present in 1 month) and relative abundance was $<1 \%$, and were considered "characteristic taxa" if constancy was $>90 \%$ (taxa present at least in 11 months). Concerning taxa distribution along sampling stations, "exclusive taxa" were found only in one station (if relative abundance $>1 \%$ monthly), while "common taxa" were found at all stations. Species have been considered dominant when showing a relative abundance $>25 \%$ at least in 1 month. Samples with monthly abundance $<1 \%$ of the annual abundance of each station (CH-Feb, RO-Jan, VA-Jan, VA-Nov, PC-Oct, SI-Aug, SP-Jan, SP-Dec, SG-Oct, SG-Nov, SG-Dec, GU-Nov) were not considered to determine exclusive, common and dominant taxa.

To determine space-temporal differences between indices and abundances of the species, a two-way ANOVA was used and homogeneity of variances was checked with Barlett's test. When variances were significantly different, data were log-transformed.

\section{Results}

Seasonal changes of temperature and salinity depthintegrated values from bottom to surface, at $5 \mathrm{~m}$ intervals, based on measurements made synchronously with the plankton sampling are presented in Fig. 2. No significant differences were found between stations of the same zone, thereby these were considered hydrologically homogeneous.

A seasonal pattern was clear for temperature and salinity in the three zones (ANOVA; $P<0.001$ ), although salinity changes were less significant at Algeciras Bay (ANOVA; $P<0.01)$. On the other hand, significant spatial differences in temperature and salinity were found between Algeciras Bay stations and the remaining ones (ANOVA; $P<0.001$ ). This was due to temperature values appreciably lower than those found at Cádiz Bay stations and salinity values significantly higher than those from Guadalquivir Estuary and Cádiz Bay. However, significant spatial differences between Guadalquivir Estuary and Cádiz Bay stations were only found for salinity values (ANOVA; $P<0.05$ ).

At $\mathrm{CH}$ station (Guadalquivir Estuary) salinity was significantly correlated with rainfall $(r=-0.78)$, and after great precipitation a short-lasting stratification was recorded, appearing a superficial water layer with salinities lower than 10 .

Total decapod larval abundance was also significantly higher at Cádiz Bay stations than at Guadalquivir Estuary and Algeciras Bay Fig. 3) (ANOVA; $P<0.01$ ). Moreover, a seasonal abundance pattern was also clear at Cádiz Bay sampling stations, whereas at Guadalquivir Estuary and Algeciras Bay no significant temporal differences were found.

The maximum densities in Cádiz Bay were observed at RO and PC stations in March and in March and June, respectively. In contrast, at VA station larval abundance was similar during all the sampling period.

Of the total individuals collected $76.3 \%$ were in the first larval stage. In Cádiz Bay, in particular, specimens in first larval stage represented $89 \%$ of the collected larvae.

A total of 69 decapod larvae taxa were recorded in this study, most of them belonging to coastal species. Nevertheless, this taxa amount could be higher since the lack of keys to species level of many zoeal forms and the problems of 

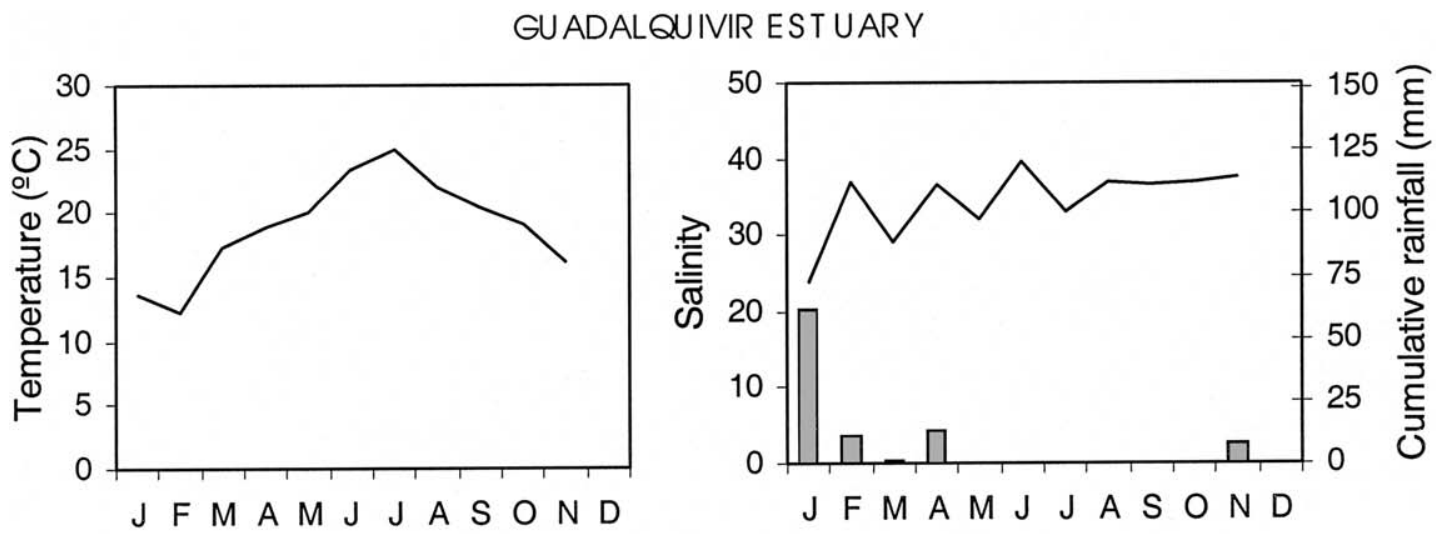

\section{CADIZ BAY}
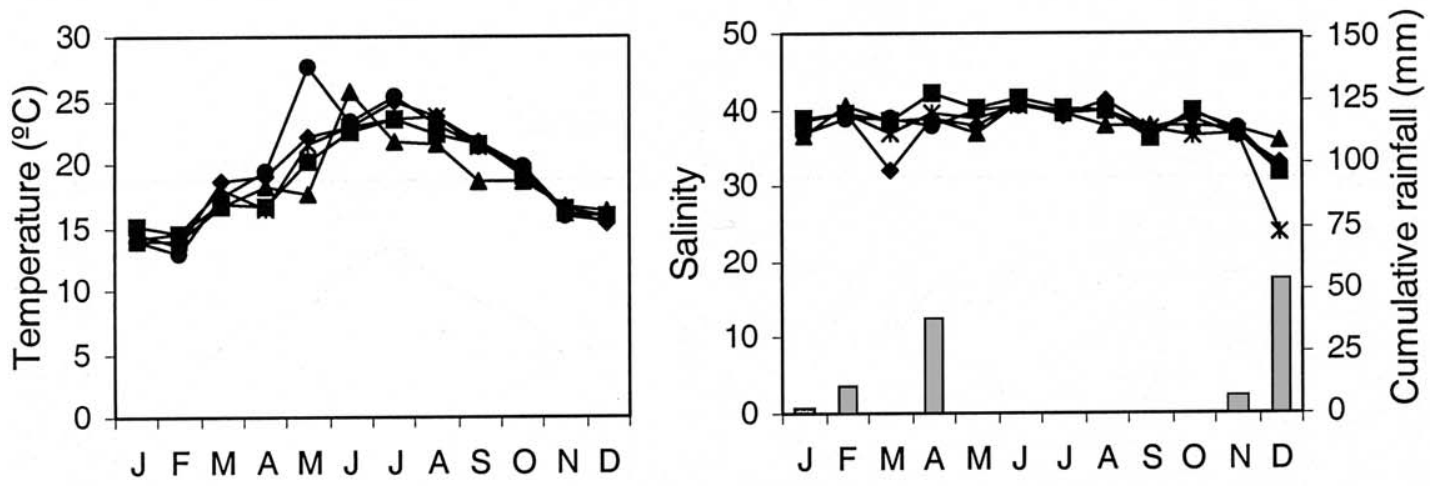

ALGE CIRAS BAY
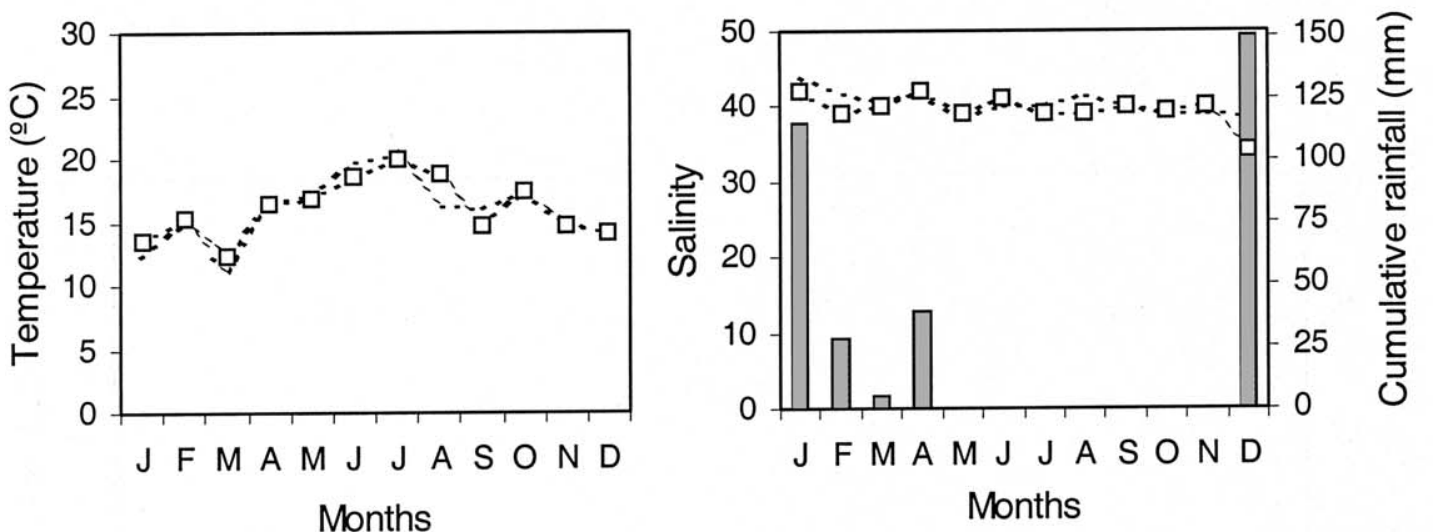

$\longrightarrow \mathrm{CH} \rightarrow-\mathrm{RO}-\mathrm{x}-\mathrm{VA} \longrightarrow \mathrm{PC}$

$\longrightarrow \mathrm{SI} \longrightarrow \mathrm{SP} \quad \ldots . . \mathrm{SG} \quad \ldots . \mathrm{G} \ldots \mathrm{GU}$

Fig. 2. Seasonal variations in water temperature and salinity at the study sites. The values are means of measurements from surface to bottom at $5 \mathrm{~m}$ intervals. Cumulative rainfall $(\mathrm{mm})$ during the week before each sampling moment is shown in graph bar.

identification of larvae (e.g. Liocarcinus spp. (Clark, 1984)) was certainly a limitation for this investigation.

Gathered in the higher decapod taxa, Brachyura were represented by 29 taxa, Caridea by 20 taxa, Anomura by nine taxa, Thalassinidea by six taxa, Dendrobranchiata by four taxa, and Palinura by only one taxon. The remaining decapod infraorders, as Astacidea and Stenopodidea, were not recorded in any station. Relative abundance and seasonal changes in dominance for these taxa at each station are shown in Table 1 and Fig. 4, respectively.

In Cádiz Bay stations, Brachyura was among the most significant taxa in terms of relative abundance, with annual median values $>35 \%$. In spite of highest brachyuran abundance values occurred during spring-time, maximum dominance were recorded during cold months (November-March) with monthly values reaching $98 \%$, mainly due to high abun- 

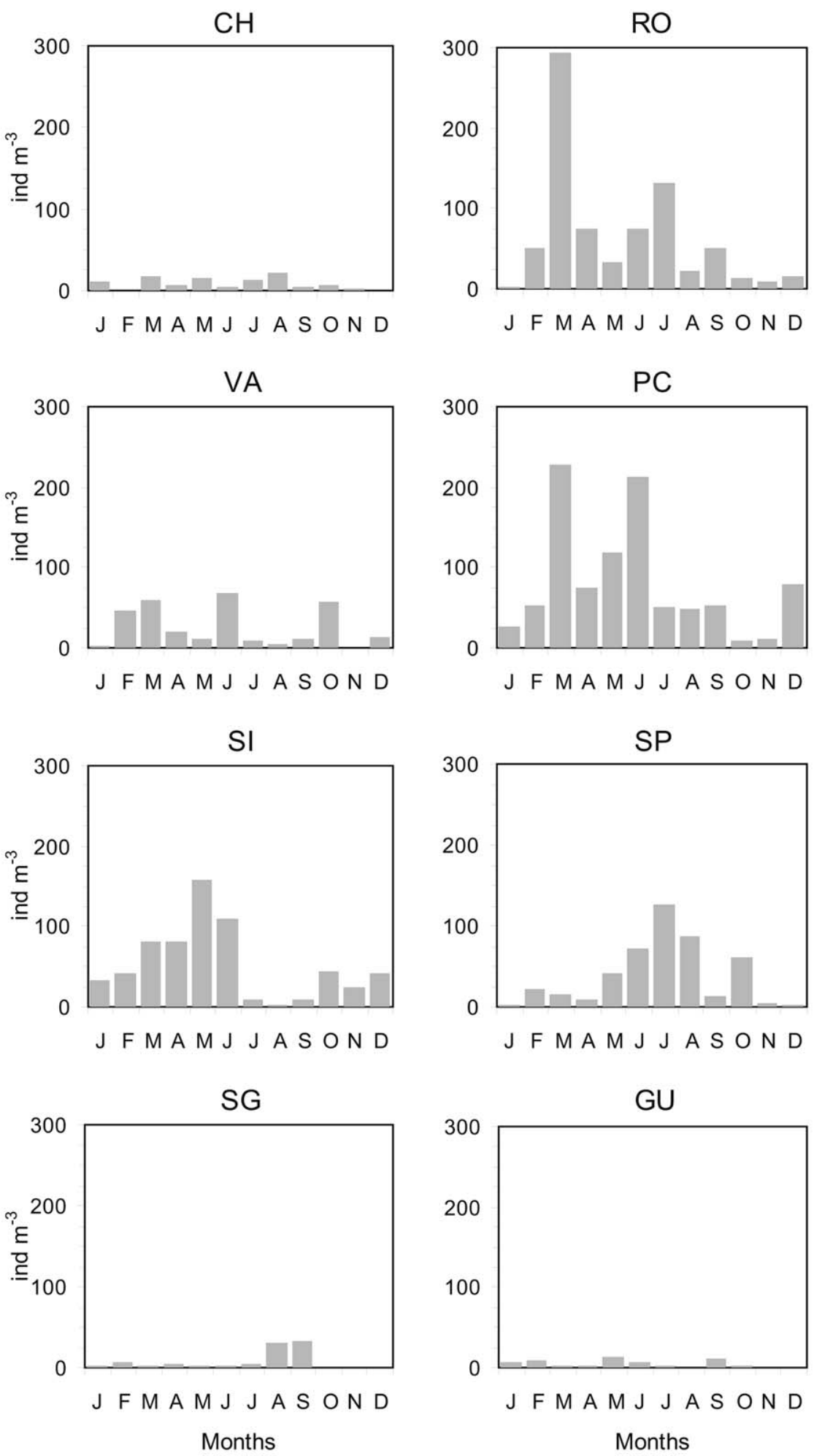

Fig. 3. Seasonal changes in abundance (individual $\mathrm{m}^{-3}$ ) at different sampling stations.

dance of Liocarcinus spp. (January-March) and C. maenas (November-December). A second Brachyura dominance peak was also observed along the warmer months (MayAugust), reaching in some stations to $85 \%$ of the total decapods. Nevertheless, it was now mainly due to the presence of
Xantho spp., I. nucleus and U. tangeri. In SI station, in particular, Brachyura dominance was clear during almost all the year, showing an average annual value of $70.5 \%$. The second-most dominant infraorder in Cádiz Bay (except at SP station) was Caridea, with annual values from $17.2 \%$ to 
Table 1

Annual relative abundance $(\%)$ of the major taxa of decapods at the stations studied

\begin{tabular}{|c|c|c|c|c|c|c|c|c|}
\hline \multirow[t]{2}{*}{ Taxa } & \multicolumn{8}{|c|}{ Stations } \\
\hline & $\mathrm{CH}$ & $\mathrm{RO}$ & VA & PC & SI & $\mathrm{SP}$ & SG & $\mathrm{GU}$ \\
\hline Dendrobranchiata & 2.9 & 0.3 & 0.8 & 0.1 & 0.7 & 0 & 1.0 & 0.3 \\
\hline Caridea & 27.7 & 29.3 & 22.8 & 25.6 & 17.2 & 16.5 & 14.3 & 14.8 \\
\hline Thalassinidea & 3.9 & 8.8 & 3.4 & 14.7 & 6.7 & 17.9 & 35.2 & 5.1 \\
\hline Palinura & 0 & 0.2 & 0.1 & 0 & 0 & 0.1 & 0.2 & 0 \\
\hline Anomura & 23.3 & 25.5 & 18.7 & 7.5 & 4.9 & 19.2 & 20.4 & 45.4 \\
\hline Brachyura & 42.3 & 35.8 & 54.2 & 51.9 & 70.5 & 46.3 & 28.8 & 34.3 \\
\hline
\end{tabular}

$29.3 \%$, due to high abundance of Hippolyte spp. Anomura was other important group in Cádiz Bay, which reached monthly dominance values of $63 \%$, due to P. longicornis. Thalassinidea also showed higher proportion from May to September, mainly at SP station and mostly due to the presence of Upogebia sp. At Guadalquivir Estuary, dominance values of Brachyura were found similar to those of Cádiz Bay stations. Caridea and Anomura also had high dominance values at $\mathrm{CH}$ station, the former mostly in April and September and the last in March and October. By the other hand, Brachyura were less dominant in Algeciras Bay stations, standing out only at GU station in cold months by Pilumnus spp. Thalassinidea was the most dominant taxon at SG station, exceeding 93\% of total abundance in August and September due to Upogebia spp., whereas Anomura was the main dominant infraorder at GU station showing values between $43 \%$ and $75 \%$ from April to September due to D. pugilator.

In the three zones, absolute and relative abundance values were insignificant for Palinura and Dendrobranchiata, standing out only the Dendrobranchiata species Sicyonia carinata at $\mathrm{CH}$ station, that represented $20.7 \%$ of monthly abundance in July.

In Table 2, the different taxa found at the eight stations are given, with their respective dominance and constancy percentage. The total number of taxa found at each station was slightly higher at Cádiz Bay than at Guadalquivir Estuary and Algeciras Bay. According to constancy index and relative abundance, 44 (64\%) different taxa were considered "rare" in some occasion, among them $11(16 \%)$ were rare every time they appeared: Melicertus kerathurus, Lysmata seticaudata, Palaemon longirostris, Plesionika sp., Axius stirhynchus, Callianassa tyrrhena, Callocaris sp., Eurynome sp., Homola barbata, Pachygrapsus transversus and Thia scutellata. Conversely, 10 "characteristic taxa" were recorded in some stations, but none of the species was considered characteristic in the eight stations. On the other hand, 10 "exclusive taxa" were considered: Gennadas elegans (at SG station), Palaemon elegans (SP), Palaemonetes varians (SP), Pandalina brevirostris (SG), C. tyrrhena $(\mathrm{CH})$, Callocaris sp. $(\mathrm{CH})$, Calcinus tubularis (GU), Galathea squamifera $(\mathrm{GU})$, Maja crispata (SG), and Medorippe lanata (SP). Moreover, 11 taxa were considered "common taxa" in all stations: Athanas nitescens, Hippolyte spp., Philocheras spp., Processa spp., Upogebia sp., D. pugilator, P. longicornis, C. maenas, Liocarcinus spp., Pilumnus spp., and Xantho spp.
Attending to relative abundance, 12 taxa were considered "dominant" at least in one station: Hippolyte spp., Philocheras spp., Upogebia sp., D. pugilator, P. longicornis, Brachynotus spp., C. maenas, I. nucleus, Liocarcinus spp., Pilumnus spp., U. tangeri, Xantho spp. These taxa represented $87 \%$ of the collected individuals. Temporal variation of the abundance in dominant taxa is shown in Fig. 5a-b.

Liocarcinus spp. and C. maenas were the most representative and abundant taxa during cold months, in which Liocarcinus spp. represented $>53 \%$ of the total decapod larvae during the January-March period, while C. maenas represented $>46 \%$ in the October-December period. Moreover, Liocarcinus spp. was the most abundant taxon in this study, tabulating 188 and 146 individual $\mathrm{m}^{-3}$ at $\mathrm{RO}$ and $\mathrm{PC}$ stations, respectively.

Conversely, five taxa showed a summery pattern, restricting its presence exclusively to warm months (AprilSeptember). Xantho spp. was the most abundant taxon in this period, pointed up with 111 individual $\mathrm{m}^{-3}$ in May at SI station, but it was the main dominant taxon only at $\mathrm{CH}$ and SI stations. Upogebia sp. presented high abundance in PC and SP stations and it was the first dominant taxon at PC, SP and SG. In this last station, it represented $91 \%$ of the total decapod larvae for the May-September period, recording the highest values of taxon abundance ( 32 individual $\mathrm{m}^{-3}$ ) for Algeciras Bay stations. The species I. nucleus was more abundant in June and July and it was clearly dominant at VA station, figuring $>33 \%$ of the total larvae in summer. This species was one of the few to have all larval stages collected, suggesting that its life cycle is completed within Cádiz Bay. $U$. tangeri was present only in the May-August period, showing the higher abundance at SP station with 28 individual $\mathrm{m}^{-3}$, while Brachynotus sp. had a wider period of presence (from January to September) but was only the main dominant taxon in April at SP station, with abundance values not exceeding 12 individual $\mathrm{m}^{-3}$.

Taxa P. longicornis, Hippolyte spp., Philocheras spp., D. pugilator, and Pilumnus spp. were present all the year round, although the period of its maximum abundance and dominance varied among stations. P. longicornis presented an abundance peak at RO station (April) of 46 individual $\mathrm{m}^{-3}$, and another one at SP station (October) of 49 individual $\mathrm{m}^{-3}$, and it was the mainly dominant taxon in March, April, June and October at several stations. Hippolyte spp. abundance and dominance varied all over the study period, but they were specially important at VA station in October, reaching values 

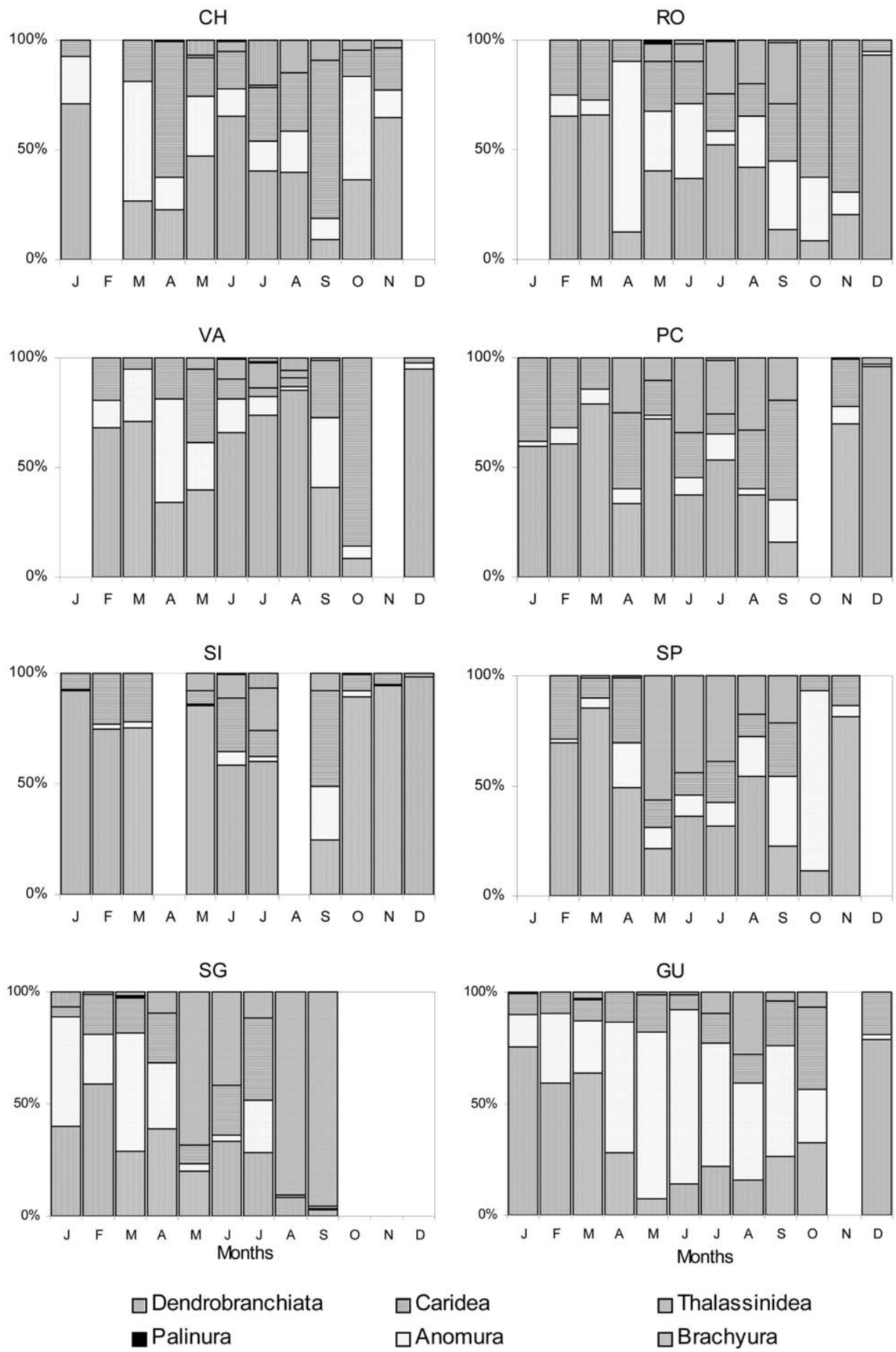

Fig. 4. Seasonal changes in abundance percentage of higher decapod taxa.

of 43 individual $\mathrm{m}^{-3}$ and $76 \%$, respectively. Philocheras spp. attained maximum values of 10 individual $\mathrm{m}^{-3}$ at SI station in April, and it was dominant only in RO station in October $(36 \%)$ due to the decrease in abundance showed by the other taxa. The irregularity of the seasonal distribution of these taxa may have hidden the occurrence of several abundant species. D. pugilator was also present throughout the year and showed maximum abundance values for the different stations in different times, although these did not reach 15 individual $\mathrm{m}^{-3}$. However, this species was the main dominant at GU station from April to October, representing 61\% of the total decapod larvae in this period. Pilumnus spp. showed low abundance values all the year round, quite higher in summer, but it only presented high dominance in winter at Algeciras Bay station, although due to abundance decrease showed by Liocarcinus spp. and C. maenas in these stations. Thus, three distinct seasonal abundance patterns were observed among dominant taxa: (i) species with larvae present 
Table 2

List of taxa collected with the corresponding annual abundance percentage (\%D) and constancy (\%C) at each sampling station. The \# sign indicates that the taxa presented $>25 \%$ abundance at least in 1 month

\begin{tabular}{|c|c|c|c|c|c|c|c|c|c|c|c|c|c|c|c|c|}
\hline \multirow[t]{2}{*}{ Taxa } & \multicolumn{2}{|l|}{$\mathrm{CH}$} & \multicolumn{2}{|l|}{$\mathrm{RO}$} & \multicolumn{2}{|l|}{ VA } & \multicolumn{2}{|l|}{$\mathrm{PC}$} & \multicolumn{2}{|l|}{ SI } & \multicolumn{2}{|l|}{ SP } & \multicolumn{2}{|l|}{ SG } & \multicolumn{2}{|l|}{ GU } \\
\hline & $\% \mathrm{D}$ & $\% \mathrm{C}$ & $\% \mathrm{D}$ & $\% \mathrm{C}$ & $\% \mathrm{D}$ & $\% \mathrm{C}$ & $\% \mathrm{D}$ & $\% \mathrm{C}$ & $\% \mathrm{D}$ & $\% \mathrm{C}$ & $\% \mathrm{D}$ & $\% \mathrm{C}$ & $\% \mathrm{D}$ & $\% \mathrm{C}$ & $\% \mathrm{D}$ & $\% \mathrm{C}$ \\
\hline \multicolumn{17}{|l|}{ Dendrobranchiata } \\
\hline Gennadas elegans & & & & & & & & & & & & & 0.1 & 16.7 & & \\
\hline Melicertus kerathurus & $<0.05$ & 9.1 & & & $<0.05$ & 8.3 & & & & & & & $<0.05$ & 8.3 & & \\
\hline Sergestes sp. & & & & & & & & & & & & & 0.1 & 16.7 & 0.4 & 25.0 \\
\hline S. carinata & 3.7 & 27.3 & 0.4 & 25.0 & 0.1 & 25.0 & 0.1 & 25.0 & 0.1 & 16.7 & & & & & & \\
\hline \multicolumn{17}{|l|}{ Caridea } \\
\hline Alpheus dentipes & $<0.05$ & 9.1 & 0.2 & 41.7 & & & 5.0 & 41.7 & $<0.05$ & 8.3 & $<0.05$ & 8.3 & 0.2 & 33.3 & 0.1 & 8.3 \\
\hline Athanas nitescens & 1.6 & 45.5 & 0.3 & 50.0 & 0.1 & 25.0 & 0.7 & 50.0 & 0.5 & 33.3 & 1.4 & 50.0 & 1.8 & 66.7 & 2.4 & 50.0 \\
\hline Caridion sp. & $<0.05$ & 9.1 & $<0.05$ & 16.7 & & & & & & & & & & & & \\
\hline Crangon crangon & 0.4 & 54.5 & 0.1 & 50.0 & 1.1 & 41.7 & 0.1 & 41.7 & 0.2 & 41.7 & 1.2 & 75.0 & & & 0.1 & 8.3 \\
\hline Dichelopandalus & 0.1 & 18.2 & 0.2 & 58.3 & 0.5 & 33.3 & & & & & 0.1 & 33.3 & 0.2 & 16.7 & 0.1 & 8.3 \\
\hline \multicolumn{17}{|l|}{ bonnieri } \\
\hline Eualus occultus & 14.2 & 90.9 & 0.3 & 41.7 & 0.7 & 33.3 & 0.2 & 58.3 & 0.1 & 33.3 & 0.2 & 33.3 & 0.2 & 33.3 & 0.2 & 33.3 \\
\hline Lysmata seticaudata & & & 0.1 & 8.3 & & & & & & & & & & & & \\
\hline Palaemon aspersus & 0.2 & 36.4 & $<0.05$ & 41.7 & $<0.05$ & 16.7 & 0.2 & 33.3 & 0.1 & 16.7 & $<0.05$ & 16.7 & 0.2 & 25.0 & 0.1 & 8.3 \\
\hline P. elegans & $<0.05$ & 9.1 & $<0.05$ & 8.3 & $<0.05$ & 16.7 & 0.1 & 33.3 & 0.1 & 25.0 & 0.1 & 33.3 & & & & \\
\hline P. longirostris & $<0.05$ & 9.1 & & & & & & & & & & & & & & \\
\hline P. serratus & 0.1 & 18.2 & $<0.05$ & 8.3 & $<0.05$ & 25.0 & $<0.05$ & 8.3 & $<0.05$ & 8.3 & $<0.05$ & 16.7 & $<0.05$ & 8.3 & 0.1 & 8.3 \\
\hline Palaemonetes varians & & & & & $<0.05$ & 25.0 & $<0.05$ & 25.0 & 0.1 & 16.7 & 0.1 & 25.0 & & & 0.2 & 8.3 \\
\hline Pandalina brevirostris & & & & & & & $<0.05$ & 8.3 & & & & & 0.2 & 25.0 & 0.2 & 16.7 \\
\hline Philocheras fasciatus & & & 0.1 & 41.7 & 0.5 & 41.7 & 0.3 & 58.3 & 0.3 & 41.7 & 0.3 & 58.3 & $<0.05$ & 8.3 & & \\
\hline Philocheras spp. & 3.0 & 81.8 & $5.1 \#$ & 91.7 & 4.4 & 100.0 & 2.2 & 100.0 & 5.1 & 100.0 & 3.0 & 91.7 & 1.1 & 33.3 & 3.1 & 75.0 \\
\hline Plesionika sp. & & & $<0.05$ & 8.3 & $<0.05$ & 16.7 & $<0.05$ & 8.3 & & & $<0.05$ & 8.3 & & & 0.1 & 8.3 \\
\hline Processa spp. & 4.7 & 63.6 & 8.8 & 100.0 & 2.6 & 91.7 & 4.1 & 100.0 & 2.6 & 100.0 & 4.7 & 91.7 & 2.5 & 83.3 & 6.1 & 91.7 \\
\hline Thoralus cranchii & 0.3 & 18.2 & 0.7 & 83.3 & 0.3 & 16.7 & 0.5 & 91.7 & 0.3 & 66.7 & 1.9 & 83.3 & 0.2 & 33.3 & 0.8 & 75.0 \\
\hline Thalassinidea & & & & & & & & & & & & & & & & \\
\hline Axius stirhynchus & & & $<0.05$ & 8.3 & & & & & & & & & & & & \\
\hline Callianassa sp. & 3.6 & 18.2 & $<0.05$ & 16.7 & 0.1 & 25.0 & 0.1 & 41.7 & 0.1 & 33.3 & $<0.05$ & 25.0 & 0.1 & 8.3 & & \\
\hline Jaxea nocturna & & & $<0.05$ & 16.7 & $<0.05$ & 8.3 & $<0.05$ & 16.7 & $<0.05$ & 16.7 & 0.1 & 25.0 & & & & \\
\hline Upogebia sp. & 1.2 & 63.6 & $8.7 \#$ & 58.3 & 2.0 & 58.3 & $15.8 \#$ & 75.0 & 4.4 & 66.7 & $28.0 \#$ & 66.7 & $71.0 \#$ & 58.3 & $2.3 \#$ & 58.3 \\
\hline Palinura & & & & & & & & & & & & & & & & \\
\hline Scyllarus posteli & & & 0.2 & 41.7 & $<0.05$ & 33.3 & $<0.05$ & 8.3 & $<0.05$ & 8.3 & $<0.05$ & 33.3 & 0.1 & 16.7 & & \\
\hline Anomura & & & & & & & & & & & & & & & & \\
\hline Anapagurus spp. & $<0.05$ & 9.1 & $<0.05$ & 16.7 & & & $<0.05$ & 8.3 & & & $<0.05$ & 16.7 & 0.4 & 33.3 & 2.5 & 25.0 \\
\hline Calcinus tubularis & & & & & & & & & & & & & 0.1 & 16.7 & 0.1 & 16.7 \\
\hline Clibanarius & & & & & & & & & & & 0.1 & 25.0 & 0.1 & 16.7 & & \\
\hline erythropus & & & & & & & & & & & & & & & & \\
\hline Diogenes pugilator & 7.6 & 100.0 & $6.2 \#$ & 100.0 & $11.1 \#$ & 100.0 & 2.7 & 100.0 & 0.5 & 83.3 & 6.0 & 75.0 & $4.9 \#$ & 66.7 & $43.0 \#$ & 91.7 \\
\hline Galathea squamifera & & & $<0.05$ & 16.7 & & & & & & & $<0.05$ & 8.3 & & & 0.3 & 25.0 \\
\hline Pagurus spp. & & & 0.1 & 50.0 & $<0.05$ & 16.7 & 0.1 & 33.3 & & & 0.1 & 33.3 & 0.2 & 25.0 & 0.9 & 16.7 \\
\hline Pisidia longicornis & $15.1 \#$ & 100.0 & $12.0 \#$ & 91.7 & $3.8 \#$ & 83.3 & 4.0 & 100.0 & 2.4 & 100.0 & $12.9 \#$ & 83.3 & 1.2 & 50.0 & 2.3 & 58.3 \\
\hline Porcellana platycheles & 1.5 & 54.5 & 1.0 & 83.3 & 0.8 & 58.3 & 0.2 & 50.0 & 0.1 & 41.7 & 0.1 & 66.7 & 0.1 & 25.0 & 0.2 & 16.7 \\
\hline Spiropagurus elegans & & & $<0.05$ & 16.7 & & & & & & & & & & & 0.1 & 8.3 \\
\hline Brachyura & & & & & & & & & & & & & & & & \\
\hline Acanthonyx lunulatus & & & $<0.05$ & 8.3 & & & & & & & $<0.05$ & 33.3 & 0.1 & 16.7 & & \\
\hline Achaeus cranchii & & & 0.2 & 41.7 & $<0.05$ & 16.7 & $<0.05$ & 16.7 & & & 0.1 & 25.0 & & & 0.1 & 8.3 \\
\hline Atelecyclus & & & 0.2 & 41.7 & 0.3 & 16.7 & $<0.05$ & 8.3 & $<0.05$ & 8.3 & 0.6 & 58.3 & 1.2 & 58.3 & 0.4 & 25.0 \\
\hline undecimdentatus & & & & & & & & & & & & & & & & \\
\hline Brachynotus spp. & 4.2 & 63.6 & 3.0 & 58.3 & 3.9 & 58.3 & 0.7 & 58.3 & 1.5 & 50.0 & $1.7 \#$ & 41.7 & 0.1 & 25.0 & 1.7 & 41.7 \\
\hline Carcinus maenas & $3.4 \#$ & 72.7 & $1.9 \#$ & 58.3 & $9.6 \#$ & 66.7 & $6.7 \#$ & 83.3 & $26.0 \#$ & 66.7 & $4.4 \#$ & 100.0 & 0.4 & 50.0 & $6.2 \#$ & 75.0 \\
\hline $\begin{array}{l}\text { Corystes } \\
\text { cassivelaunus }\end{array}$ & 0.1 & 9.1 & 0.7 & 25.0 & 0.9 & 33.3 & $<0.05$ & 8.3 & $<0.05$ & 27.3 & 0.1 & 33.3 & & & & \\
\hline Ebalia spp. & 0.1 & 27.3 & $<0.05$ & 33.3 & $<0.05$ & 16.7 & 0.1 & 33.3 & $<0.05$ & 8.3 & $<0.05$ & 16.7 & 0.1 & 16.7 & 0.2 & 16.7 \\
\hline
\end{tabular}




\begin{tabular}{|c|c|c|c|c|c|c|c|c|c|c|c|c|c|c|c|c|}
\hline \multirow[t]{2}{*}{ Taxa } & \multicolumn{2}{|l|}{$\mathrm{CH}$} & \multicolumn{2}{|l|}{$\mathrm{RO}$} & \multicolumn{2}{|l|}{ VA } & \multicolumn{2}{|l|}{$\mathrm{PC}$} & \multicolumn{2}{|l|}{ SI } & \multicolumn{2}{|l|}{ SP } & \multicolumn{2}{|l|}{ SG } & \multicolumn{2}{|l|}{ GU } \\
\hline & $\% \mathrm{D}$ & $\% \mathrm{C}$ & $\% \mathrm{D}$ & $\% \mathrm{C}$ & $\% \mathrm{D}$ & $\% \mathrm{C}$ & $\% \mathrm{D}$ & $\% \mathrm{C}$ & $\% \mathrm{D}$ & $\% \mathrm{C}$ & $\% \mathrm{D}$ & $\% \mathrm{C}$ & $\% \mathrm{D}$ & $\% \mathrm{C}$ & $\% \mathrm{D}$ & $\% \mathrm{C}$ \\
\hline Ethusa mascarone & $<0.05$ & 9.1 & 0.1 & 41.7 & $<0.05$ & 16.7 & 0.1 & 41.7 & 0.1 & 25.0 & $<0.05$ & 16.7 & & & & \\
\hline Eurynome sp. & & & & & & & & & & & & & & & 0.1 & 8.3 \\
\hline Goneplax rhomboides & & & & & & & & & & & & & & & 0.2 & 16.7 \\
\hline Homola barbata & & & & & & & & & & & & & $<0.05$ & 8.3 & & \\
\hline Ilia nucleus & 0.3 & 18.2 & $8.1 \#$ & 50.0 & $6.7 \#$ & 33.3 & 1.6 & 50.0 & 0.6 & 25.0 & 0.1 & 33.3 & & & & \\
\hline Inachus spp. & & & $<0.05$ & 25.0 & $<0.05$ & 16.7 & $<0.05$ & 16.7 & & & & & & & 0.1 & 8.3 \\
\hline Liocarcinus spp. & $9.0 \#$ & 90.9 & $26.7 \#$ & 91.7 & $27.0 \#$ & 91.7 & $28.0 \#$ & 100.0 & $16.1 \#$ & 75.0 & $5.3 \#$ & 91.7 & $4.9 \#$ & 91.7 & 6.1 & 83.3 \\
\hline Macropodia spp. & $<0.05$ & 9.1 & 0.1 & 75.0 & 0.3 & 33.3 & 0.4 & 83.3 & 0.3 & 75.0 & 0.1 & 58.3 & & & & \\
\hline Maja crispata & & & $<0.05$ & 16.7 & $<0.05$ & 8.3 & $<0.05$ & 25.0 & $<0.05$ & 8.3 & $<0.05$ & 25.0 & 0.1 & 25.0 & & \\
\hline Medorippe lanata & & & $<0.05$ & 8.3 & & & & & & & 1.5 & 33.3 & 0.6 & 41.7 & & \\
\hline Neopinnotheres & 1.8 & 63.6 & 1.2 & 83.3 & 2.1 & 66.7 & 1.4 & 66.7 & 0.8 & 58.3 & 0.8 & 75.0 & & & 0.1 & 16.7 \\
\hline pinnotheres & & & & & & & & & & & & & & & & \\
\hline Pachygrapsus & 0.7 & 27.3 & 0.3 & 41.7 & 0.4 & 25.0 & 0.7 & 50.0 & 0.1 & 16.7 & & & & & 0.2 & 25.0 \\
\hline P. transversus & & & & & & & & & & & $<0.05$ & 8.3 & & & 0.1 & 8.3 \\
\hline Parthenope & 0.1 & 9.1 & 0.1 & 33.3 & 0.5 & 16.7 & 0.5 & 33.3 & 1.3 & 33.3 & $<0.05$ & 25.0 & & & & \\
\hline angulifrons & & & & & & & & & & & & & & & & \\
\hline Pilumnus spp. & 7.1 & 90.9 & 2.2 & 83.3 & 0.6 & 50.0 & 1.2 & 83.3 & 0.4 & 66.7 & 4.3 & 83.3 & 3.7 & 75.0 & $14.7 \#$ & 83.3 \\
\hline Pinnotheres pisum & & & $<0.05$ & 33.3 & $<0.05$ & 8.3 & 0.1 & 41.7 & $<0.05$ & 16.7 & 0.1 & 33.3 & $<0.05$ & 8.3 & 0.2 & 8.3 \\
\hline Pirimela denticulata & 0.6 & 18.2 & 0.1 & 50.0 & 0.1 & 16.7 & $<0.05$ & 25.0 & $<0.05$ & 8.3 & 0.8 & 75.0 & 0.9 & 50.0 & 1.6 & 66.7 \\
\hline Pisa spp. & & & $<0.05$ & 8.3 & $<0.05$ & 8.3 & $<0.05$ & 8.3 & & & $<0.05$ & 8.3 & 0.2 & 16.7 & 0.2 & 8.3 \\
\hline Portumnus latipes & 0.2 & 9.1 & 0.1 & 58.3 & $<0.05$ & 25.0 & 0.7 & 25.0 & & & 0.1 & 16.7 & $<0.05$ & 8.3 & 0.8 & 41.7 \\
\hline Sirpus zariquieyi & 0.1 & 18.2 & $<0.05$ & 8.3 & $<0.05$ & 8.3 & & & & & $<0.05$ & 8.3 & 0.8 & 41.7 & 0.9 & 41.7 \\
\hline Thia scutellata & & & & & & & & & $<0.05$ & 8.3 & & & & & & \\
\hline Uca tangeri & 2.0 & 36.4 & 2.1 & 25.0 & $1.0 \#$ & 25.0 & $5.4 \#$ & 33.3 & 4.0 & 41.7 & $14.0 \#$ & 33.3 & & & & \\
\hline Xantho spp. & $12.2 \#$ & 36.4 & 1.9 & 33.3 & 0.9 & 41.7 & $9.2 \#$ & 50.0 & $26.0 \#$ & 50.0 & 4.5 & 50.0 & 1.2 & 41.7 & 0.1 & 16.7 \\
\hline Total taxa number & 41 & & 54 & & 47 & & 47 & & 40 & & 50 & & 42 & & 44 & \\
\hline Rare taxa number & 13 & & 9 & & 6 & & 8 & & 8 & & 6 & & 8 & & 15 & \\
\hline $\begin{array}{l}\text { Characteristic taxa } \\
\text { number }\end{array}$ & 5 & & 6 & & 5 & & 7 & & 4 & & 4 & & 1 & & 2 & \\
\hline Dominant taxa number & 4 & & 8 & & 7 & & 6 & & 4 & & 6 & & 3 & & 4 & \\
\hline
\end{tabular}

in non-warm months (Liocarcinus spp., C. maenas); (ii) species present in warmer months (Upogebia sp., I. nucleus, Brachynotus spp., U. tangeri, Xantho spp.); (iii) species present all the year round (Hippolyte spp., Philocheras spp., D. pugilator, P. longicornis, Pilumnus spp.).

Fig. 6 shows the variation in diversity, specific richness and evenness at each station during the study period. Diversity was highest (2.66) at RO station in May and lowest $(0.28)$ at SI station in November. Evenness varied from 0.93 at SG station in October to 0.11 at SG station in September, while species richness ranged from 4.94 at SP station in August to 1.01 at SI station in November. Significant temporal differences, at each station, were observed only among values of diversity and species richness indices (two-way ANOVA, $P<0.01)$. Aside from Algeciras Bay stations, in which there was not a clear seasonal pattern, diversity was generally higher during April-September period due to an increase in species number. Conversely, no significant spatial and temporal differences of evenness index were observed between the three zones. Thus, the diversity pattern seems to depend exclusively on the variation of species number. Abrupt fluctuations of species richness and diversity indexes, between consecutive months, were very important at Algeciras Bay stations.

\section{Discussion}

In the Guadalquivir Estuary the high inflow of freshwater is an important source of allochthonous nutrients to the coastal environment. Despite the mineral contribution for a high primary production in many estuaric systems (Sautour and Castel, 1995), rainfall runoff in this lightly turbid estuary causes a decline of primary production, especially in the maximum turbidity zone (Drake et al., 1999). This high variability appears to affect the larval populations of decapods, which are not able to develop in areas of high environmental instability. Criales and Anger (1986) showed that the larvae of Crangon crangon, generally considered a very euryhaline species, develop in a narrow salinity range. Thus, the occurrence of low salinities seems to inhibit or to make difficult the larval development of many decapod species. Therefore, the low number of species found and the low abundance values recorded in the Guadalquivir Estuary zone can be a reflex of these environmental conditions.

Notwithstanding the proximity to the Guadalquivir Estuary, salinity pattern was different at Cádiz Bay, where the freshwater inflow is more scarce, only affecting VA station (located in the mouth of the Guadalete River). At this station, 

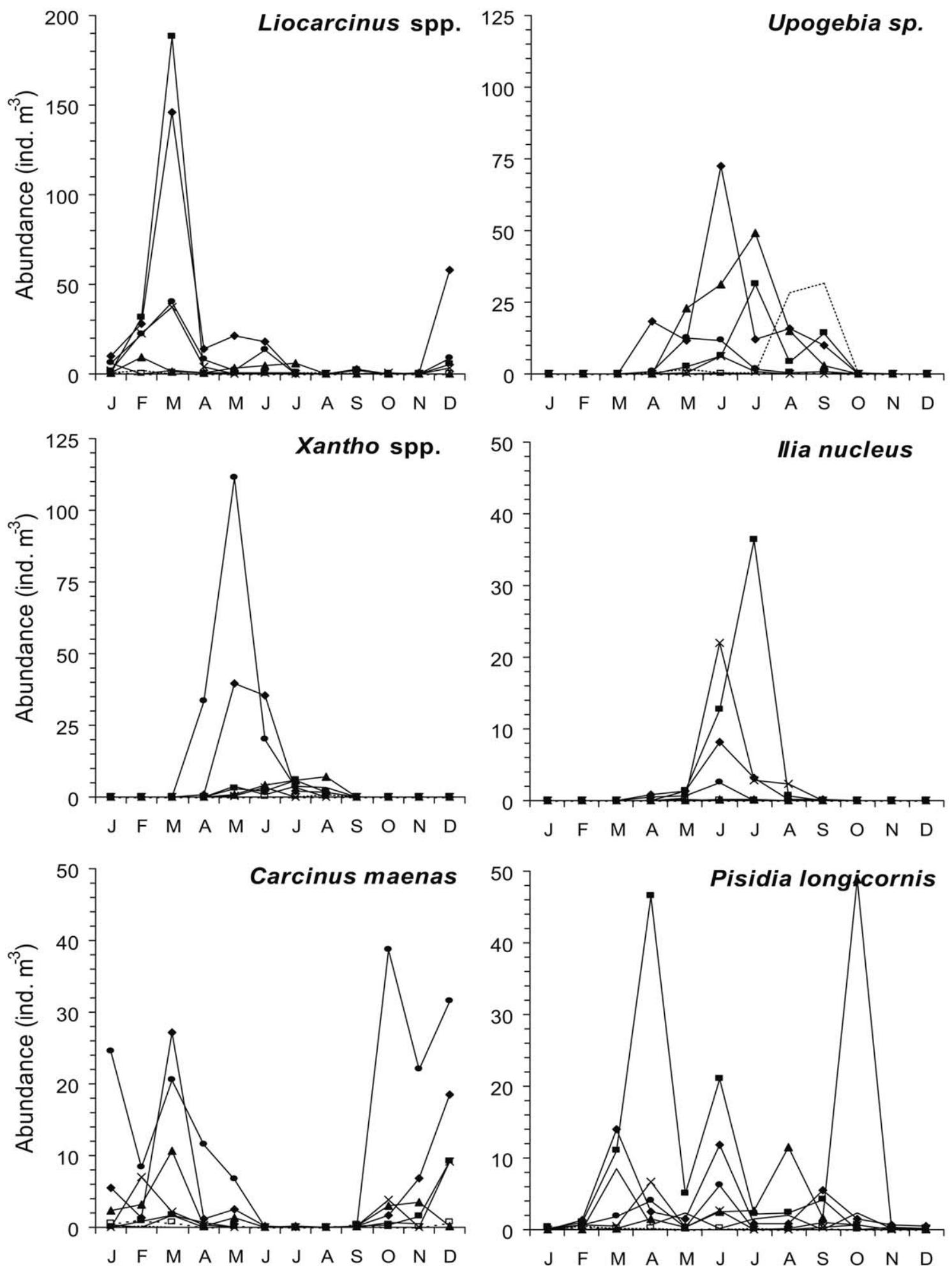

Fig. 5(a). Abundance temporal fluctuations of dominant taxa.

salinity values were lower during and after high precipitation events (in December) due to the freshwater discharge from the Guadalete River, although a clear stratification was not recorded. Moreover, a continuous tidal renewal of the water mass, estimated from 76 to $112 \mathrm{hm}^{3}$ (Muñoz and SánchezLamadrid, 1994), reduces the occasional high changes in temperature and salinity values. Thus, as there are no strong variations of the main hydrological variables that affect larval development, it is possible to sustain the high larval abundance observed in this zone.

In Algeciras Bay, the continuous renewal and mix of water masses by currents proceeding from Mediterranean Sea or 

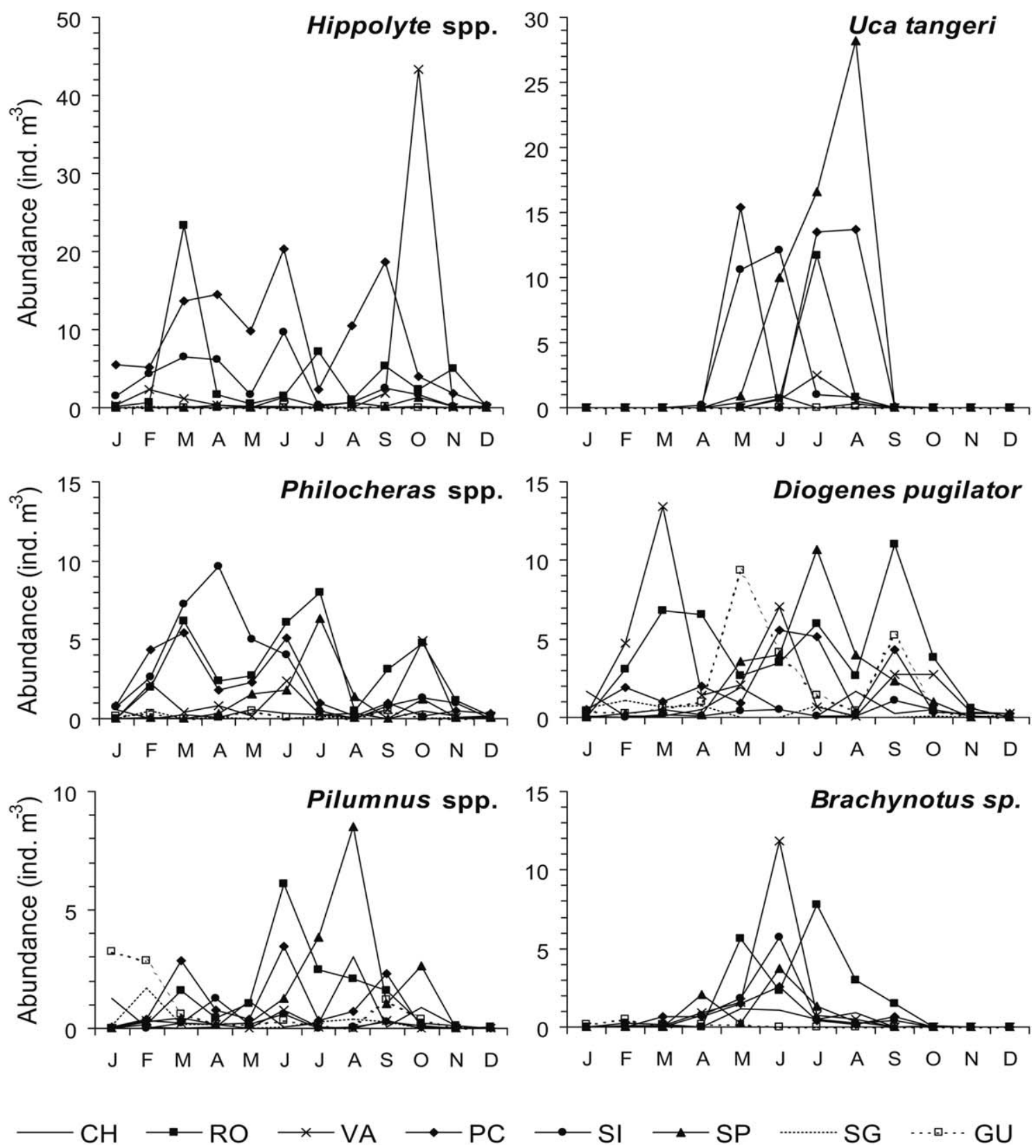

Fig. 5(b). Continuation.

Atlantic Ocean (Conradi, 1995), are still more pronounced than in the other two sampling sites. This phenomenon minimises most abrupt changes in salinity that could follow the intense precipitation periods usually registered in this zone. The low abundance values for each taxon reflects the predominant off-shore influence in this zone, resulting in assemblages constituted by few individuals and where dominance changes are easily observed. The presence of deep-sea currents in this zone was also evident by the capture of deepwater species, as G. elegans and Sergestes spp. whose adults were recorded at $400 \mathrm{~m}$ depth underneath (Nöel, 1992). In general, values of temperature and salinity herein recorded, were, respectively, lower and higher than those recorded in Guadalquivir Estuary and Cádiz Bay. In SG station, where Upogebia sp. showed densities comparable to the remaining

zones, the abundance peak occurred in August and September, in opposition to Cádiz Bay where maximum values were recorded in June and July. Maximum abundance values of Upogebia sp. have also been reported in the same period in the Portuguese coast (Paula, 1987), where a decrease in temperature during early summer is caused by local upwelling conditions. Kinne (1970) referred to the temperature as the main factor determining species breeding period. Thus, the presence of cool water and the warming delay of water masses could retard the reproductive period of this species at the Algeciras Bay.

Differences in nutrients and chlorophyll values, from water samples collected during this study (unpublished data), suggest that the nutritional conditions are not the same in the three zones. Data referring to primary productivity values 

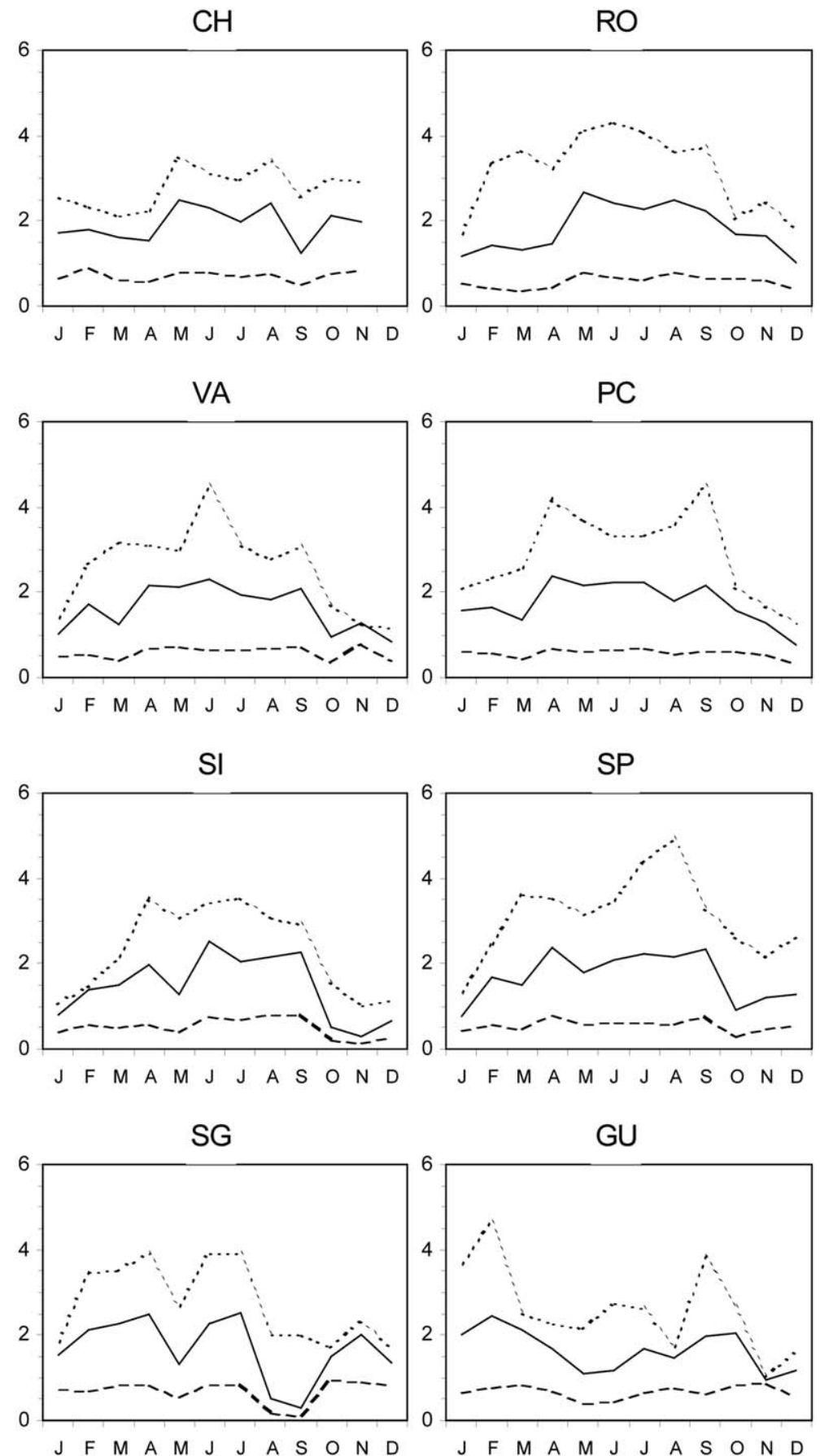

— DIVERSTY

SPECIES RICHNESS

EVENNESS

Fig. 6. Seasonal changes in diversity, species richness and evenness indexes at different sampling stations.

show that these were higher at Cádiz Bay while in Algeciras bay they were very low. The high chlorophyll $a$ concentrations observed in Cádiz Bay were similar to those registered in previous studies (Muñoz and Sánchez-Lamadrid, 1994). According to Rhyter (1969), a planktonic system dominated by easily grazed and assimilated phytoplankton species, contribute to higher secondary and tertiary production values. Nevertheless, whereas decapod larvae are generally able to eat and convert phytoplankton, mainly small species (Criales and Anger, 1986), for decapod larvae assemblages a higher availability of small herbivorous zooplankters is more useful (e.g. Copepoda) developed after phytoplankton blooms. In this way, Fusté and Gili (1991) showed how high primary productivity can enhance the development of a rich population of decapod larvae. Thus, the occurrence of periodic phytoplankton blooms in Cádiz Bay would support a high decapod larval abundance, in contrast to other poorer zones that are nevertheless not very far away (as Algeciras Bay). 


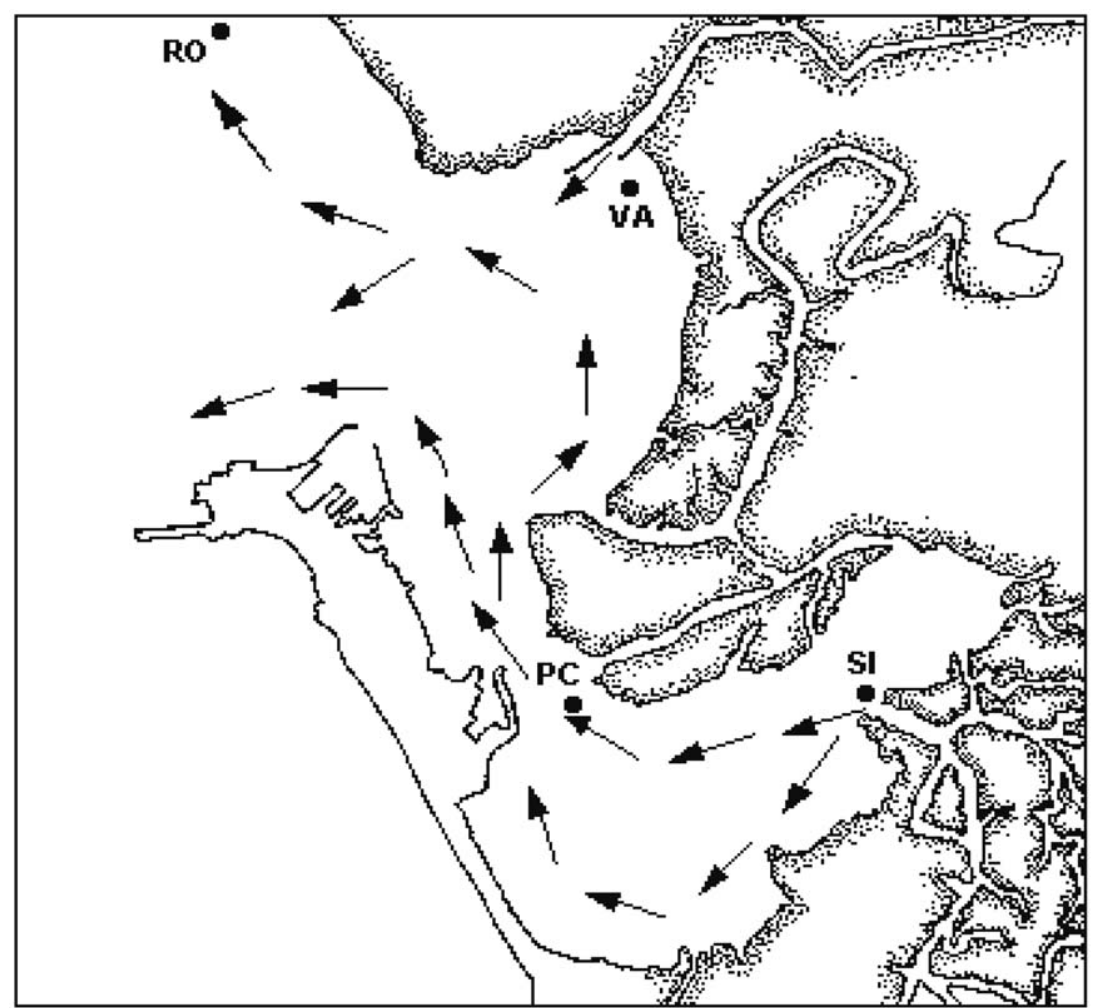

Fig. 7. Tidal currents circulation model (outflow moment) in Cádiz Bay.

On the other hand, local abundance differences registered between VA station and the remaining Cádiz Bay stations, might relate to the water circulation in the area, which agrees with Paula et al. (1998) who considers that characteristics of plankton distribution in coastal habitats are strongly influenced by tidal currents. According to Alvarez et al. (1999), an outflow from the inner to the outer Bay is observed during tidal cycles. The mentioned outflow Fig. 7 could carry specimens from the inner Bay (PC and SI stations) towards the outer Bay (RO station). This model of circulation may have influence in the dispersion of larval population and might explain the lowest abundance values at VA station, where the outflow has no influence, in opposition to the highest concentration of larvae observed at RO station, where a lot of individuals can be massed.

Based on these considerations, and noting the similarity with decapod distribution patterns observed in the coast of Galicia (NW-Iberian Peninsula) (Fusté and Gili, 1991), it would be expected that hydrological heterogeneity along the coast of Cádiz Gulf could give rise to changes in the overall distribution pattern of planktonic organisms. The difference in abundance presented by the three zones reinforces the hypothesis that a specific influence of temperature and salinity is a significant factor determining the seasonality and spatial distribution of decapod larvae assemblages.

In temperate latitudes it seems to be common that in zooplankton assemblages decapod larval abundance is significantly higher during the warm season than during the colder (Cunha, 1993; Siokou-Frangou, 1996; Valdés et al., 1990), and it is closely related to the environmental changes in the water column, such as surface heating and cooling, stratification and mixing, and other central ecological processes (Valdés and Moral, 1998). In this sense, a seasonal pattern was patent at Cádiz Bay sampling stations, coinciding with the well-marked seasonality of hydrological conditions, whereas at Guadalquivir Estuary and Algeciras Bay no significant temporal differences were found. Similarly to the one observed for Cádiz bay, seasonal abundance patterns have been reported by previous studies in adjacent areas, as in S. Torpes Bay and Mira Estuary in Portugal (Paula, 1987, 1993) or in Ebro Delta in Spain (Fusté, 1987). Nevertheless, the annual average abundance registered during this research at Cádiz Bay was higher than that recorded in those studies. Moreover, abundance values presented by these last two studies did not reach 100 individual $\mathrm{m}^{-3}$, while at Cádiz Bay a maximum of 315 individual $\mathrm{m}^{-3}$ was recorded. Particularly, C. maenas abundance pattern in Cádiz bay contrasts with data reported to Mira Estuary (where it was present all the year) (Paula, 1993) and to Atlantic northern coasts (where it was recorded from January to September) (Broekhuysen, 1936; Crothers, 1968; Klein-Breteler, 1975, 1976). Nevertheless, the temperature values registered in Mira Estuary, when larvae of $C$. maenas were collected, were similar to values recorded in this study. This coincidence agrees with Mileikovsky (1970) that suggests that reproductive cycles follow, in general, universal ecological patterns.

On the other hand, the high number of specimens collected in the first larval stage in this area shows the relevant hatchery role that this zone plays, suggesting a posterior high larval exportation of the following stages (for export and 
import patterns see Drake et al. (1999), Rodríguez (1981) and Pereira et al. (2000)). Although there is a high number of decapod species coinciding in breeding-time in late summer, a decrease in larval abundance seemed common in Cádiz Bay stations during this period. Nevertheless, this diminution was not followed by a decrease in diversity. Drake and Arias (1991b) reported an increase of fish larvae and juveniles in spring-summer at Cádiz, and suggested that higher temperatures induce higher ingestion rates. Thus, the observed variations in density may be associated with the annual development of fishes, suggesting a possible control of zooplankton density by predator pressure. Moreover, a certain regulation of zooplankton has been reported in inshore areas where fish populations have been implied, explaining changes in the composition of zooplankton (Fulton, 1984).

\section{Acknowledgements}

This work is part of a Ph.D. thesis of J.I. GonzálezGordillo on planktonic larval stages of decapods from SW Spain, supported by Consejería de Medio Ambiente de la Junta de Andalucía (Project 110/95) and Consejo Superior de Investigaciones Científicas (CSIC). We thank L.J. Taracido and S. González for their help in lab work and Dr. P. Drake for her useful comments and suggestions. Also, thanks to all persons of Instituto de Ciencias Marinas de Andalucía (ICMAN-CSIC) who offered us much help and friendly ambience during this research. Special thanks are due to Dr. Antonina M. Dos Santos (IPIMAR-Portugal) for her assistance during the identification of specimens.

\section{References}

Alvarez, O., Izquierdo, A., Tejedor, B., Mañanes, R., Tejedor, L., Kagan, B.A., 1999. The influence of sediment load on tidal dynamics, a case study: Cadiz Bay. Estuar. Coast. Shelf. Sci 48, 439-450.

Azeiteiro, U.M., Marques, J.C., Ré, P., 1999. Zooplankton annual cycle in the Mondego river Estuary (Portugal). Arq. Mus. Boc. 3, 239-264.

Benavente, J., Gracia, F.J., López-Aguayo, F., 2000. Empirical model of morphodynamic beachface behaviour for low-energy mesotidal environments. Mar. Geol. 167, 375-390.

Broekhuysen, G.J., 1936. On development, growth and distribution of Carcinides maenas. Arch. Neerl. Zool. 2, 255-399.

Clark, P.F., 1984. A comparative study of zoeal morphology in the genus Liocarcinus (Crustacea, Brachyura, Portunidae). Zool. J. Linn. Soc. 82, 273-290.

Conradi, M., 1995. Distribución espaciotemporal de los peracáridos (Crustacea) asociados a Bugula neritina (L, 1758) en la bahía de Algeciras. Aspectos faunisticos y zoogeográficos. Ph.D. thesis, University of Sevilla, Sevilla, pp. 210.

Criales, M.M., Anger, K., 1986. Experimental studies on the larval development of the shrimps Crangon crangon and C. allmanni. Helgölander Meeresunters 40, 241-265.

Crothers, J.H., 1968. The biology of the shore crab Carcinus maenas L. The background: anatomy, growth and life history. Fld. Stud. 2, 407-434.

Cunha, M.E., 1993. Seasonal variation of the zooplankton biomass over the Portuguese continental shelf. ICES Statutory Meeting 1993/L 62, 1-7.

Dos Santos, A.M., 1999. Larvas de crustaceos decápodes o largo da costa portuguesa. Ph.D. thesis, University of Lisboa, pp. 278.
Drake, P., Arias, A.M., 1991. Ichthyoplankton of a shallow coastal inlet in south-west Spain: factors contributing to colonisation and retention. Estuar. Coast. Shelf. Sci. 32, 347-364.

Drake, P., Arias, A.M., 1991. Composition and seasonal fluctuations of the ichthyoplankton community in a shallow tidal channel of the Cádiz Bay (Spain). J. Fish Biol. 39, 245-263.

Drake, P., Arias, A.M., 1993. Larval feeding habits and diel rhythms of four species of marine fish in a tidal creek of Cádiz Bay (Spain). In: Walther, B.T., Fyhn, H.J. (Eds.), Physiologyand Biochemistry of Fish Larvae. University of Bergen, pp. 153-159.

Drake, P., Arias, A.M., Rodríguez, A., 1998. Seasonal and tidal abundance patterns of decapod crustacean larvae in a shallow inlet (SW Spain). J. Plank. Res. 20, 585-601.

Drake, P., Baldó, F., Cuesta, J.A., García, D., Silva, A., Arias, A.M., Rodríguez, A., Sobrino, I., Fernández, C., 1999. Initial effects of the toxic waste spill (Aznalcóllar mine accident) on the aquatic macrofauna of the Guadalquivir Estuary. Sci. Total Environ. 242, 271-280.

Fernández-Delgado, C., Drake, P., Arias, A.M., García-González, D., 2000. Peces de Doñana y su entorno. Organismo Autónomo Parques Nacionales. Ministerio de Medio Ambiente, Madrid, pp. 272.

Fulton, R.S., 1984. Predation, production and the organization of an estuarine copepod community. J. Plank. Res. 6, 399-415.

Fusté, X., 1982. Ciclo anual de las larvas de Crustáceos Decápodos de la costa de Barcelona. Inv. Pesq. 46, 287-303.

Fusté, X., 1987. Els crustacis decàpodes del Delta de l'Ebre. Ph.D. thesis, University of Barcelona, pp. 195.

Fusté, X., 1990. Crustáceos Decápodos de la Bahía de els Alfacs (Delta del Ebro). Inv. Pesq, pp. 618-623.

Fusté, X., Gili, J.M., 1991. Distribution pattern of decapod larvae off the north-western Iberian Peninsula coast (NE Atlantic. J. Plank. Res. 13, 217-228.

González-Gordillo, J.I., Dos Santos, A., Rodríguez, A., 2001. Checklist and annotated bibliography of decapod Crustacea larvae from the Southwestern European coast (Gibraltar Strait area). Sci. Mar. 61-65, 275-305.

Kinne, O., 1970. Temperature: invertebrates marine ecology. In: Kinne, O. (Ed.), Marine Ecology 1. Wiley-Interscience, New York, pp. 407-514.

Klein-Breteler, W.C.M., 1975. Growth and moulting of juvenile shore crabs, Carcinus maenas, in a natural population. Neth. J. Sea Res 9, 86-99.

Klein-Breteler, W.C.M., 1976. Settlement, growth and production of the shore crab, Carcinus maenas, on tidal flats in the Dutch Wadden Sea. Neth. J. Sea Res. 10, 354-376.

Locke, A., Corey, S., 1988. Taxonomic composition and distribution of Euphausiacea and Decapoda (Crustacea) in the neuston of the Bay of Fundy, Canada. J. Plank. Res. 10, 185-198.

Mileikovsky, S.A., 1970. Seasonal and daily dynamics in pelagic larvae of marine shelf bottom invertebrates in nearshore waters of Kandalaksha Bay (White Sea). Mar. Biol. 5, 180-194.

Muñoz, J.L., Sánchez-Lamadrid, A., 1994. El medio físico y biológico en la bahía de Cádiz: saco interno. Informe Técnico 28/94. Junta de Andalucía, Sevilla, pp. 161.

Nöel, P.Y., 1992. Clé preliminaire d'identification des Crustacea Decapoda de France et des principales autres espèces d'Europe. Muséum National d'Historie Naturelle. Collection Patrimoines Naturels 9, Paris, pp. 145.

Paula, J., 1987. Seasonal distribution of Crustacea Decapoda larvae in S. Torpes bay, South-western Portugal. Inv. Pesq. 51 (Suppl. 1), 267-275.

Paula, J., 1989. Rhythms of larval release of decapod Crustaceans in the Mira Estuary, Portugal. Mar. Biol. 100, 309-312.

Paula, J., 1993. Ecologia da fase larvar e recrutamento de crustáceos decápodes no Estuário do Rio Mira. Ph.D. thesis, University of Lisboa, Lisboa, pp. 282.

Paula, J., Pinto, I., Guambe, I., Monteiro, S., Gove, D., Guerreiro, J., 1998. Seasonal cycle of planktonic communities at Inhaca Island, southern Mozambique. J. Plank. Res. 20, 2165-2178.

Pereira, F., Pereira, R., Queiroga, H., 2000. Flux of decapod larvae and juveniles at a station in the lower Canal de Mira (Ria de Aveiro, Portugal) during one lunar month. Inv. Repr. Dev. 38, 183-206. 
Rodríguez, A., 1981. Biología y cultivo del langostino Penaeus kerathurus (Forskal, 1775) del Golfo de Cádiz. Ph.D. thesis, University of Sevilla, Sevilla, pp. 210.

Rodríguez, A., Drake, P., Arias, A.M., 1997. Reproductive periods and larval abundance patterns of the crabs Panopeus africanus and Uca tangeri in a shallow inlet (SW Spain). Mar. Ecol. Prog. Ser. 149, 133-142.

Rhyter, J.H., 1969. Photosynthesis and fish production in the sea. Science $166,72-76$.

Roff, J.C., Davidson, K.G., Pohle, G., Dadswell, M.J., 1984. A guide to the marine flora and fauna of the Bay of Fundy and Scotia shelf: larvae: decapoda: Brachyura. Can. Tech. Rep. Fish. Aquat. Sci. 1322, 1-57.
Sautour, B., Castel, J., 1995. Comparative spring distribution of zooplankton in three macrotidal European estuaries. Hydrobiology 311, 139-151.

Siokou-Frangou, I., 1996. Zooplankton annual cycle in a mediterranean coastal area. J. Plank. Res. 18, 203-223.

Valdés, L., Moral, M., 1998. Time-series analysis of copepod diversity and species richness in the southern Bay of Biscay off Santander. Spain, in relation to environmental conditions. ICES J. Mar. Sci. 55, 783-792.

Valdés, J.L., Román, M.R., Alvarez-Ossorio, M.T., Gaudens, A.L., Miranda, A., 1990. Zooplankton composition and distribution off the coast of Galicia, Spain. J. Plank. Res. 12, 629-643.

Vives, F., 1979. Sur les larves des Crustacés Décapodes des Costes de Viscaya (nord de l'Espagne) pendant 1976. CIEM CM 1979/L 19, 1-8. 